\title{
Coercion Through IOs: The Security Council and the Logic of Information Transmission
}

\author{
Alexander Thompson
}

\begin{abstract}
Why do powerful states often channel coercive policies through international organizations (IOs)? The article explains this phenomenon by theorizing the political advantages of working through a neutral institution, defined as one with heterogeneous and representative member preferences. The argument centers on the notion of strategic information transmission. IO involvement sends information about the coercer's intentions and the consequences of the coercive policy to foreign leaders and their publics, information that determines the level of international support offered to the coercing state. The logic helps explain why the United Nations Security Council plays a unique role in approving and disapproving the use of force. A case study of the 1990-91 Gulf War shows how these information transmission mechanisms work in practice and that the rationalist information argument provides more traction than a legitimacy-based alternative explanation.
\end{abstract}

Why do powerful states channel coercive foreign policies through international organizations (IOs)? Governments that lack resources or expertise often require IO assistance for material and technical reasons, and weak states rely on international forums to increase their political clout and bargaining power. Powerful states, by contrast, typically do not need IOs to achieve specific objectives. On the contrary, because turning to an international institution complicates policymaking and entails some loss of autonomy, one might expect powerful states to avoid such entanglements. Yet even superpowers sometimes channel coercive actions, including the use of force, through IOs, despite viable alternatives that offer more flexibility and control—namely unilateralism and ad hoc multilateralism. The liter-

For valuable comments on earlier drafts, I would like to thank Charles Glaser, Peter Gourevitch, Lloyd Gruber, Darren Hawkins, Keith Krehbiel, David Lake, Charles Lipson, Daniel Nielson, Kenneth Schultz, Duncan Snidal, Michael Tierney, Daniel Verdier, Erik Voeten, and Joel Westra, as well as participants in the PIPES workshop at the University of Chicago and the conference on Delegation to International Organizations at the University of California, San Diego. I also thank Lisa Martin and two anonymous reviewers for constructive suggestions. I am grateful to Matthew Scherbarth for research assistance and to the Mershon Center at Ohio State University for financial assistance. 
ature lacks a coherent explanation of the political logic for conducting coercion through IOs. Understanding this behavior has implications for important theoretical debates-engaging a range of rationalist and constructivist scholarship—over the role of formal institutions in international politics.

IOs have played a prominent if uneven role in statecraft since World War II. Even in the Cold War environment, the United States turned to the United Nations (UN) for the Korea intervention and sought cover from regional organizations to take action in Cuba, the Dominican Republic, Panama, and Grenada. ${ }^{1}$ Since the Cold War, powerful states have increasingly turned to IOs when using force. The United States has achieved endorsements from the UN Security Council or the North Atlantic Treaty Organization (NATO), or both, for virtually every intervention since 1990, including those in Iraq, Somalia, Bosnia, Rwanda, Haiti, Zaire, Kosovo, and Afghanistan. The British have behaved similarly and pushed hard for a Security Council resolution authorizing the 2003 Iraq war. Russia and France have also sought UN or regional cover for interventions in the "near abroad" and francophone Africa, respectively. Some middle powers, including Germany, Japan, and Canada, simply will not intervene without an IO mandate.

The Security Council has come to play a uniquely important role in this regard. Even in cases where the Council failed to endorse intervention policies, as in Kosovo in 1999 and Iraq in 2003, there was a concerted effort to gain such approval. Security Council enforcement powers have been employed with dramatically increased frequency-more than two hundred Chapter VII resolutions were passed between 1990 and 2004, compared to only seven during the Cold War-and its practice of authorizing coalitions of states to conduct coercive actions is well established and increasingly common. ${ }^{2}$ As one UN scholar concludes, "The most important development in Council decision-making since 1990 has been its disposition to authorize the use of force." ${ }^{3}$ The widespread hostility to the most recent Iraq war, and specifically the decision to bypass the UN, further illustrates the importance attached to IOs and especially the Security Council when it comes to the use of force. Indeed, intervention without some effort to gain approval is now virtually obsolete, a remarkable feature of contemporary international relations that merits both theoretical and policy attention.

I shed light on this phenomenon by exploring the political advantages of conducting coercion through a formal, standing organization. Borrowing insights from

1. The relevant bodies were the Organization of American States (OAS) in the first three cases and the Organization of East Caribbean States in Grenada. In the end, the OAS did not endorse the Panama intervention.

2. This is a conclusion of the so-called Brahimi Report, commissioned by the Secretary-General to study UN peacekeeping practices. UN Doc. A/55/305-S/2000/809, 21 August 2000. Most invocations of Chapter VII have come in the context of peacekeeping missions and do not qualify as coercive interventions. However, these operations are often complex and evolve toward a mixture of consent and coercion, sometimes with extensive authority to use force. See Fenton 2004; Roberts 2004 , $136-39$.

3. Malone 1998, 22. 
the literature on delegation to domestic political institutions, especially U.S. congressional committees, I present a theoretical framework for explaining why and under what conditions states turn to IOs in the conduct of statecraft. I conceptualize IOs as agents of the international community (including both leaders and their publics) that serve to constrain and assess the policies of potential coercing states, thereby generating politically important information that can be used to screen desirable from undesirable actions. Under certain conditions, coercers have incentives to subject their actions to such scrutiny and limitations because doing so lowers the political costs of exercising power. The effect of IO involvement is especially important when the organization is more politically neutral, a function of the distribution of interests among the institution's members. A neutral IO is less likely to share the preferences of the coercer in terms of the means, timing, and goals of a policy and is more likely to be viewed as credible in the eyes of the international community. Coercing states face a tradeoff: as they turn to more neutral institutions, the constraints and the variance in outcomes increase but so do the political benefits.

My argument centers on the notion of strategic information transmission. When a coercing state works through a sufficiently neutral IO, this sends information to both foreign leaders and their publics, information that can determine the level of international support-material or political, direct or tacit-offered to the coercing government. Two processes, involving two types of information and two intended audiences, are key. First, the costs of channeling a policy through an IO allow the coercer to signal benign intentions vis-à-vis third-party states (that is, nontargets), a signal directed primarily at foreign leaders. In the context of coercion, especially by powerful states, these leaders feel threatened and are able to achieve some assurance and control through IO involvement. Second, the endorsement of a neutral IO sends policy-relevant information to foreign publics, who are "rationally ignorant" 4 of international affairs and seek information shortcuts to determine the consequences of coercion and whether it is justified. This second audience can be as important as the first because leaders are often constrained by domestic politics from supporting another state's use of force. While the international relations (IR) field has considered the strategic role of domestic publics for coercing states, ${ }^{5}$ the importance of foreign publics has been largely overlooked.

Increased international support from these two audiences is desirable for a coercing state because it determines the political costs of a given policy and may affect its long-term success. The argument applies to any case of a powerful state-one that does not require logistical support or resources from an IO to achieve its objectives-conducting a policy of coercion. While my theoretical claims have relevance for the actions of any coercing state, limiting the analysis to powerful states has the advantage of helping to isolate political variables from simple issues

4. Downs 1957.

5. See Fearon 1994; Schultz 2001; Mingst 2003. 
of capacity. I confine my discussion to coercive military interventions (thereby excluding standard peacekeeping and purely humanitarian missions), although the argument theoretically speaks to economic and diplomatic coercion as well.

The phenomenon explored here has traditionally been explained in terms of the legitimacy conferred on a state's policy by IO approval, which leads to greater international support. Since Claude's influential article, countless scholars and policymakers have pointed to the legitimation function of IOs, especially the UN. ${ }^{6}$ However, while there is a virtual consensus that this legitimation effect matters, the term is used loosely, and there is no clear theoretical understanding of how it occurs. I provide a set of causal mechanisms in the rationalist tradition to help explain why IO approval increases international political support for state policies. I also offer an informational rationale for why states have coordinated around the Security Council as the primary institutional legitimizer of the use of force. ${ }^{7}$

The article proceeds by briefly reviewing the relevant literatures on why political actors use institutional agents as a means of generating information. In particular, I introduce informational theories of legislative committees to explain why formal IOs are informative and why some institutions transmit information more efficiently than others. In the second section, I present the theoretical argument and hypotheses, and I discuss observable implications. The third section presents a case study of U.S. efforts to work through the Security Council during the 1990-91 Iraq conflict. Detailed qualitative analysis is the most appropriate method for uncovering the relevant causal mechanisms. I then briefly consider an alternative argument drawn from constructivism-and arguably reflecting the conventional wisdom - that explains the benefits of working through IOs in legitimacy terms. The final section summarizes and discusses additional implications of the argument.

\section{Power, Institutions, and Informative Agents}

For years the nexus between institutions and power remained understudied by IR theorists busy arguing that either one or the other was important. A handful of recent works shed light on why powerful states subject themselves to institutional entanglements in the security sphere. Ikenberry argues that powerful states can build institutions to exhibit "strategic restraint," a form of self-binding that lowers the costs of maintaining world order by reducing fears of domination. ${ }^{8}$ Lake explains why states sometimes go beyond mere cooperation to create "hierarchical" security relationships that protect against opportunism. ${ }^{9}$ My puzzle is distinct: I ask

6. See Claude 1966; Haass 1994; Finnemore 1996; Hurd 2002; Thompson 2005; Voeten 2005.

7. Voeten 2005.

8. Ikenberry 2001.

9. Lake 1999. 
why states work through institutions while exercising power in particular foreign policy episodes, not why they create or maintain institutions over time. Institutions are exogenous in my analysis. In this respect, my question is closer to Martin's investigation of how institutions benefit a state pursuing economic sanctions. ${ }^{10}$

Unlike these scholars, I find the information transmission role of institutions to be more important than their ability to solve commitment problems, which are less relevant in the context of a single coercive episode. While costly constraints imposed by institutions are important in my account, they serve primarily to transmit information rather than to address time-inconsistency. ${ }^{11}$ IR scholars have had a rather limited view of strategic information transmission, focusing almost exclusively on signaling games where a state's "type"-private information regarding preferences and thus intentions - is the source of uncertainty. ${ }^{12}$ My argument places equal weight on information regarding policy consequences, that is, the relationship between policy choices and their effects. Under certain conditions, IOs can provide these two types of information, intentions information and policy information, and thus states have incentives to rely on them when this information is valuable.

Political actors delegate authority to political institutions for a variety of reasons. They may do so to solve collective decision-making problems, to forge credible commitments, to reduce their workload, or to generate information. ${ }^{13}$ Information-based theories of delegation fall into two main categories, based on the type of information that is hidden: those that focus on reducing uncertainty surrounding the principal's preferences, and those that focus on the production of policy information by specialized agents. Typical of the former category, delegation to independent central banks is sometimes understood as a costly sign of a government's devotion to sound monetary policy, which can serve as a signal to investors. ${ }^{14}$ Government reliance on central banks and independent judiciaries may also signal a preference for stability or reform. Political actors also delegate to extract policy-relevant information. Because they are politically neutral and have superior expertise, for example, central banks can provide credible information to legislators and political parties regarding the government's policy choices and their

10. Martin 1992.

11. While IOs increase the costs of backing out of commitments to a particular course of action, they typically cannot solve this problem when it comes to powerful states. The U.S. decision to abandon the UN before the 2003 war against Iraq is a good example. In fact, the IR literature frequently conflates the analytically distinct problems of signaling and credible commitment. I maintain the distinction both conceptually and empirically.

12. See, for example, Fearon 1997; Kydd 2000.

13. See Kiewiet and McCubbins 1991; North and Weingast 1989; Martin 2000; and Epstein and O'Halloran 1999. For international applications and theoretical extensions, see Hawkins et al. 2006.

14. See Maxfield 1997; Hall and Franzese 1998; Keefer and Stasavage 2002. These information arguments are distinct from the classic time-inconsistency rationale for central bank independence. See Rogoff 1985. 
economic consequences. ${ }^{15}$ Bureaucrats also possess "knowledge and expertise that politicians lack," 16 and this creates incentives for legislators and executive branch officials to rely on executive agencies, even if doing so entails some loss of control. ${ }^{17}$

Even more relevant to the international sphere are informational theories of legislative organization, developed most extensively in the context of the U.S. Congress. ${ }^{18}$ Arguably, delegation to congressional committees, composed of a subset of the membership, more closely matches circumstances at the international level than does delegation to large, autonomous bureaucracies, which have fewer analogs among international institutions. Similar to these committees, IOs are composed of a subset of states in the international system. Informational theories propose that committees serve to provide information to the legislature on alternative policies and their consequences. The most important design feature is their composition in terms of member preferences, which largely determines how informative the signals sent by committees are. Specifically, a committee that is heterogeneous - that is, whose membership is diverse and "bookends" the median preference of the floor-sends more information than a homogeneous committee; and a committee composed of "preference outliers"- that is, whose membership has extreme preferences relative to the floor median-is less informative than one with a more moderate composition. While all committees have an information advantage insofar as they specialize in a substantive area, only some-those that are diverse and representative-are able to transmit information that is seen as credible and therefore informative to the legislature as a whole.

These principles of information transmission by institutional agents can be usefully applied to international institutions. I highlight the distinct role played by formal IOs, as uniquely informative among international institutions, and explain how the properties of the Security Council render it especially informative when it comes to military intervention.

\section{Coercion, IOs, and Information Transmission}

IOs as Informative Agents

Coercing states face the problem of minimizing the international political costs that might be imposed by third-party states - that is, states that are not themselves targets of coercion. These costs are potentially high when coercion is conducted unilaterally and may come in the form of short-term "active" sanctions, designed to oppose the policy directly, and longer-term "passive" sanctions, designed to

15. Bernhard 1998.

16. Huber and Shipan 2002, 2.

17. See Bawn 1995; Volden 2002.

18. See Gilligan and Krehbiel 1989 and 1990; Krehbiel 1991. 
frustrate the coercing state over time. ${ }^{19}$ Through uncooperative behavior and issuelinkage, even weak states can impose costs on the most powerful if their interests are threatened. According to one U.S. policymaker, the 1998 unilateral bombing of a chemical plant in Sudan (designed to target al Qaeda) "aggravated bilateral relationships all over the place" and made them "more difficult to manage." ${ }^{20}$ In the late 1980s, U.S. employment of "Super 301" measures to coerce its trading partners engendered substantial political backlash, complicating the Uruguay Round negotiations and regional talks. ${ }^{21}$ The situation following the 2003 Iraq war is also illustrative, as the United States has had considerable difficulty garnering cooperation for peacekeeping and reconstruction.

Formal IOs play a unique role in international affairs because of their independence, which derives from their ability to act with relative autonomy and neutrality. ${ }^{22}$ It is the neutrality of IOs in particular that allows them to serve as informative agents of the international community. Because they have standing memberships with diverse interests and cannot be controlled by individual states, they have two advantages as information generators. First, IOs are able and willing to impose constraints on a coercer, making signaling of limited ambitions possible; and second, IOs act as representatives of the international community, allowing them to generate information on policy consequences that is regarded as disinterested and thus credible. Intentions information and policy information are important to thirdparty leaders and their publics as they formulate a response to the coercive action.

Unilateral claims by a coercing state clearly lack the neutrality of IOs in the eyes of the international community. Simple multilateralism, as an intermediate strategy between unilateralism and IO-based action, provides only limited information; ad hoc coalitions are by definition composed of like-minded states, as the phrase "coalition of the willing" reflects. In the language of the legislative signaling literature, these coalitions are homogeneous and usually composed of preference outliers. Because the ideal point of the median member of such a coalition is close to the ideal point of the coercer on the question of intervention, the coalition is not likely to impose substantial constraints and approval from the coalition is not informative to the median member of the international community. Figure 1 maps these preferences. Among the most robust findings in theories of strategic information transmission is that actors with more similar preferences can send more informative signals to each other. ${ }^{23}$ It follows that, by itself, multilateral support of a coercer conveys little information to third parties. The involvement of a formal IO thus offers unique political benefits, beyond those conferred by multilateralism alone.

19. On this distinction, see Thomas 2001.

20. Author's interview with a senior White House official, Washington, D.C., 17 May 1999.

21. Bayard and Elliott 1994, 320-21.

22. Abbott and Snidal 1998.

23. See Crawford and Sobel 1982; Lupia and McCubbins 1994, 368. 


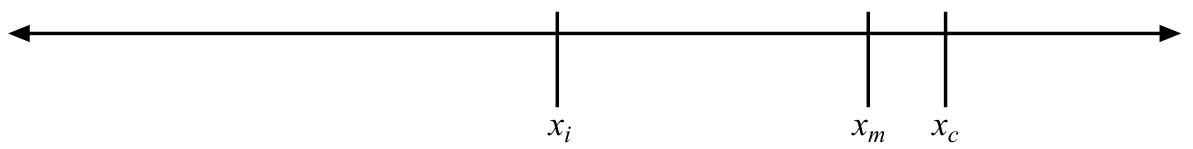

$x_{i}=$ Ideal point of median member of international community

$x_{m}=$ Ideal point of median member of multilateral coalition

$x_{c}=$ Ideal point of coercing state

FIGURE 1. Preferences with a multilateral condition

Informational theories of legislative organization help us further understand why the Security Council plays a special role when it comes to the use of force. Figure 2 presents graphically a situation where the IO membership is both heterogeneous (reflected in a wide preference distribution) and representative (reflected in a roughly normal distribution and a median preference that matches that of the international community). In security matters, the Security Council best matches these characteristics. Approval from the Security Council-with its fifteen members representing various regions, geostrategic interests, and levels of develop-

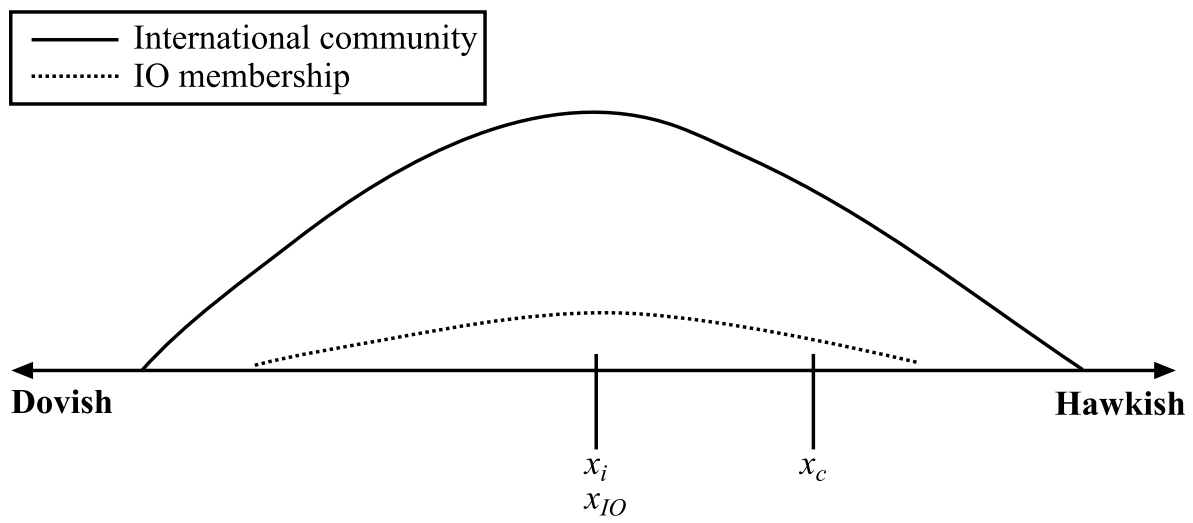

$x_{i}=$ Ideal point of median member of international community

$x_{I O}=$ Ideal point of median member of IO

$x_{c}=$ Ideal point of coercing state

FIGURE 2. Heterogeneous and representative preference distribution 
ment ${ }^{24}$ - requires nine members to vote affirmatively and the absence of a veto from any permanent member. The distance between the IO's median preference and the coercer's ideal point suggests that the organization has distinct interests. The proximity of $x_{I O}$ and $x_{i}$ and the heterogeneity of membership preferences imply that information transmission to third parties is efficient, that is, that the IO serves as an informative agent of the international community. Channeling coercion through the Security Council entails costly constraints-even a superpower usually must modify its policy and may be blocked altogether ${ }^{25}$ — but will also produce high-quality information regarding intentions and policy consequences.

This logic explains why regional organizations, with less diverse memberships and more parochial interests, produce a legitimation effect of lesser magnitude. The information argument presented here thus suggests that institutional variation presents tradeoffs-political benefits versus costly constraints-that affect the "forum shopping" decisions of coercing states, an extension of the framework explored elsewhere. ${ }^{26}$

Coercion through IOs is thus a calculated choice by the coercer to generate international support or, at least, to minimize opposition to its policy. This leads to the following general proposition: When powerful coercers work through IOs, they do so strategically to lower the international political costs of coercion. This proposition rules out the possibility that states act through IOs primarily because of an internalized desire to behave in a legitimate or appropriate way. ${ }^{27}$ By focusing on political costs and benefits, the proposition also rules out material needs and logistical support as the primary motivation. ${ }^{28}$ Finally, the argument implies that this behavior cannot be explained in terms of domestic politics within the coercing state. Two hypotheses presented below go beyond the general proposition to address specific causal mechanisms.

\section{Two Pathways of Information Transmission}

There are two channels by which IOs transmit information during coercive episodes, each centered on a different audience. I assume that state leaders are well informed about policy alternatives and consequences in the security sphere and that IOs do not have an information advantage over them in this regard. Other leaders do, however, lack information regarding the intentions of the coercing state's leadership. Coercion is associated with expanded influence, especially when pur-

24. The ten nonpermanent seats are distributed geographically, with five allocated to Asia and Africa, two each to Latin America and Europe, and one to Eastern Europe.

25. Voeten 2001.

26. Thompson 2006.

27. For a discussion of this possibility, see Hurd 1999.

28. Burden sharing is rarely a central concern for powerful states conducting military coercion (see Finnemore 1998, 183; Chapman and Reiter 2004, 901), though it is clearly valued during peacekeeping and national-building missions. 
sued by the powerful, and the precise intentions of the coercer determine how threatening its actions are and how they affect the interests of third-party states. The 2003 Iraq war provides a stark example. Before the war, governments in the region feared that the United States had ambitious goals to dominate the region, altering the strategic landscape to their disadvantage. The U.S. approach did nothing to assuage these fears. As Telhami assessed the regional mindset after the war, "Most are ... concerned that the war in Iraq was merely the opening move in a larger strategy; they ask themselves which country will be next." ${ }^{29}$

It is difficult for powerful states to reassure others that their goals are limited and unthreatening. The decision to work through a neutral IO serves as an informative signal because it imposes costs on a coercer that a more aggressive state (one with intentions that threaten third parties) would be unwilling to pay. The current IR literature certainly recognizes that institutions impose constraints on states, but conceptualization of these precise costs is not well developed. At least four overlapping costs may be imposed when coercion is channeled through an IO: freedom-of-action costs, organization costs, costs of delay, and scrutiny costs.

First, a state's freedom of action is almost always limited when coercion is channeled through an IO. History shows that IOs impose real constraints that restrict the set of policy options available to even the strongest states. ${ }^{30}$ Some policy restrictions are endogenous to the process of seeking IO approval. Once a state chooses to act through an IO, it must bring to the table a defensible set of goals to gain support, ruling out the most ambitious and aggressive policies ex ante.

Second, coercers face organization costs-including the costs of communicating, bargaining, and reaching common positions-when they work through an IO. ${ }^{31}$ These are a form of transaction costs. Any multilateral approach to foreign policy increases the costs of decision making and of implementing policy: the problems of collective decision making and coalition warfare in particular are well known. These are compounded by political factors, or what have been termed influence costs, "the losses that arise from individuals within an organization seeking to influence its decisions for their private benefit." ${ }^{32}$ In Kosovo, for example, the details and intensity of the bombing campaign were modified to keep NATO members on board. Reaching consensus among states, a requisite for IO approval, leads to outcomes that may differ from the coercer's preferences.

The third type of cost, delay, is largely a product of the first two. Involving a neutral IO implies a willingness to engage in diplomacy and to wait for approval of the policy. Finally, working through an IO increases the level of post hoc scrutiny to which a coercer is subject. Since IOs increase transparency and require a

29. Telhami 2003.

30. For examples involving the UN and OAS, see Chayes and Chayes 1995, 41-42. Even NATO, composed of like-minded states, imposed profound constraints on its superpower leader during the Cold War (Weber 1992) and the Bosnia crisis (Papayoanou 1997).

31. Olson $1965,47$.

32. Milgrom and Roberts 1990, 58. 
more public accounting of actions, the international community is able to track the behavior of a state that chooses to work under their auspices. Moreover, exchange and discourse within an IO tends to reveal information about states' preferences and intended actions, ${ }^{33}$ leading to more effective monitoring and higherquality signaling at the international level. The diversity of IO members is again key. Unlike a unilateral effort or an ad hoc coalition, most IOs include states with disparate interests who will watch the coercer with a critical eye. The presence of scrutiny leads to more sincere signaling. ${ }^{34}$

These various costs, which I refer to generally as the costs of constraint, allow the coercer to send meaningful information regarding its intentions. Showing restraint and a willingness to cede some control reassures nontarget states, which are less likely to oppose the intervention.

$H 1$ (Intentions information): Channeling coercion through an IO sends a signal of benign intentions to leaders of third-party states, thereby increasing the likelihood of international support.

However, even if other state leaders determine that supporting the coercive policy is in their national interest, they may face domestic barriers to doing so. They must convince their publics that supporting another state's use of force is justified. IO approval helps overcome this additional obstacle by sending policy-relevant information to domestic publics abroad. ${ }^{35}$

While IR scholars have paid increasing attention to how domestic publics influence state interests and policy, the role of domestic publics abroad is not well understood. Members of publics are poorly informed relative to leaders; they lack knowledge regarding the reasons for a given policy and the relationship between the policy and potential consequences. This is most acute in international affairs, where issues are less salient and publics are exposed to little debate and information. Because individuals also have negligible influence on foreign policy, each has little incentive to gather and analyze information. In the context of coercive intervention on the part of another state, publics lack policy information in two related ways. First, they do not know if the policy serves collective interests or whether it reflects selfish interests with potentially undesirable consequences. Second, they do not know if the proposed policy is a reasonable means to achieve the stated goals.

Ignorance, however, does not imply indifference. Publics seek "information shortcuts" to assess international issues, ${ }^{36}$ and IO endorsements can perform this func-

33. See Martin 1992; Wallander 1999.

34. Lupia and McCubbins 1994, 368.

35. Publics may also value information about the coercer's intentions. I assume that leaders, preoccupied with international competition, are relatively more concerned than publics about intentions information and thus emphasize the role of policy information with respect to publics.

36. Popkin 1991. 
tion. Because the claims of IOs are more neutral than claims of individual governments or ad hoc coalitions, the information they convey regarding a policy is more credible and meaningful. This is evidenced by public attitudes toward the search for weapons in Iraq before the 2003 war. Two-thirds of Canadians surveyed in January 2003 said they would believe the UN rather than the administration of U.S. President George W. Bush if there was disagreement over the state of Iraqi weapons. ${ }^{37}$ Absent a UN imprimatur, publics around the world were skeptical that the United States was seeking the collective goods of eliminating an Iraqi threat and upholding Security Council resolutions; most saw selfish goals involving oil, Israel, and political influence. ${ }^{38}$ In the context of a military intervention, as law scholar Wedgwood observes, IO authorization "can be seen as an impartial certification that an adversary does indeed pose a threat to international peace and security, and that the use of force is not intended to serve the narrow interests of a single country." 39 The logic is captured in a basic principle behind the informational rationale for committees. "In the presence of uncertainty," write Gilligan and Krehbiel, "diversity of interests on the committee promotes informational efficiency." ${ }^{40}$ Individual members of the public, like legislators, do respond to new policy information and update their beliefs in sensible ways. ${ }^{41}$

Through this process of policy information transmission to domestic publics abroad, a coercer that achieves IO approval makes it easier for foreign leaders to offer support. In "two-level games" terms, the information transmitted to publics increases the size of the domestic win-set for third-party leaders by minimizing internal opposition. This second path of information transmission is captured in a second hypothesis:

H2 (Policy information): IO approval informs domestic publics abroad that the coercive policy has desirable consequences, thereby increasing the likelihood of international support by minimizing domestic opposition.

\section{Observable Implications}

The most definitive evidence of the information transmission argument would uncover the motivations of the coercing state's leadership and would show that third parties — both leaders and publics—receive the information hypothesized and react to it accordingly. It is impossible to directly observe intentions or whether particular information has been received, though there are reasonable indicators that shed light on the processes hypothesized here, and consideration of different types of evidence can increase one's confidence.

37. Ipsos-Reid/CTV/Globe and Mail poll, released 17 January 2003.

38. Various polls on this topic are summarized in Pew Research Center 2005, chap. 7.

39. Wedgwood 2002, 173.

40. Gilligan and Krehbiel 1989, 463.

41. Shapiro and Jacobs 2000, 224. 
The framework rests on the proposition that powerful states channel coercion through IOs in a calculated effort to reduce the international political costs of coercion. Two types of evidence shed light on this argument. First, one should see leaders express that their motivation for working through an IO was indeed a desire to reduce international political fallout, and this should be confirmed by contemporaneous observers. Alternative motivations, such as a logic of appropriateness or a desire for material support from the IO, would have to be ruled out. Second, one can demonstrate that the political costs of coercion would have been higher absent IO involvement. This can be done by carefully tracing international reactions within the case and through comparisons to similar cases that vary in terms of IO involvement.

For the first hypothesis, on intentions information, one should observe the imposition of costly constraints on a coercer as a result of IO involvement. One should also adduce evidence that foreign leaders were concerned about the threat posed by the coercer, and that the costs of constraint served to allay such concerns. This is best done through in-depth case research and the use of counterfactual arguments to demonstrate that international reactions would have been different absent IO approval.

The second hypothesis - that IO approval sends policy information to domestic publics abroad-is the most empirically challenging. It is impossible to know precisely how and why individuals updated their beliefs about a given policy. One should first establish that third-party leaders are constrained by domestic opposition from supporting the coercer and that they view IO involvement as key to alleviating this problem. In terms of public opinion, a procoercion shift should occur following IO approval. One can also compare public opinion in cases that vary in terms of IO involvement; IO authorization should correlate with more favorable attitudes toward the action.

I propose an additional indicator for Hypothesis 2, based on the framing strategies of leaders, that helps capture both the concerns of publics and the information they receive during coercive episodes. If leaders believe that IOs can transmit politically useful information to their publics, one should see them frame their actions in specific ways in statements designed for public consumption. Leaders should stress not only involvement by the IO but also its informative properties, namely, its neutrality as a function of its diverse and representative membership. Because the press "index" their coverage of foreign policy to the statements of high-level government officials, ${ }^{42}$ how events are framed by these officials shapes the information received by publics. Indeed, strategic communication by leaders can even stretch across borders to reach foreign audiences directly. ${ }^{43}$ To the extent that leaders are well informed about their constituents, their framing strategies

42. Zaller and Chiu 1996.

43. Manheim and Albritton 1984. 
also should shed light on what type of information is important to publics as they assess policies.

Given these indicators, assessing the argument requires fairly detailed analysis of a given case to reveal the information transmission processes, with contextual comparisons to other cases to isolate specific variables and assess counterfactuals. The case study below is guided by the arguments and observable implications summarized in Table 1.

\section{The United States and the Security Council in the Gulf War}

Following the Iraqi invasion of Kuwait on 2 August 1990, the United States went to great lengths to work through the UN to pressure and ultimately expel Iraq from Kuwait, seeking Security Council resolutions at every stage of the conflict. Resort to force came only after twelve resolutions condemning Iraq and imposing various sanctions, culminating in the passage on 29 November of Resolution 678, which authorized member states "to use all necessary means." Most observers of Gulf War diplomacy agree that by turning to the Security Council the United States

TABLE 1. Hypotheses and observable implications

Hypothesis

General Proposition: When powerful coercers work through IOs, they do so strategically to lower the international political costs of coercion.

\section{H1 (Intentions information):}

Channeling coercion through an IO sends a signal of benign intentions to leaders of third-party states, thereby increasing the likelihood of international support.

H2 (Policy information): IO approval informs domestic publics abroad that the coercive policy has desirable consequences, thereby increasing international support by minimizing domestic opposition.
Observable implications

- Do leaders express that they are motivated by this rationale?

- Does IO approval generate greater international support?

- Do comparable cases of unilateral coercion entail greater political costs for coercers?

- Does the IO impose costly constraints on the coercer?

- Are third-party leaders concerned about the intentions of the coercer?

- Are third-party leaders less concerned about the threat posed by the coercer (and more likely to offer support) following IO involvement?

- Are third-party leaders constrained by domestic publics in deciding whether to support the coercer?

- Does public opinion shift following IO approval of the coercion policy?

- Is international public support greater than in comparable cases with no IO approval?

- In public statements, do leaders use framing strategies that stress IO involvement and the IO's informative design properties? 
was able to "legitimate" and achieve greater support for its use of coercion. But few analysts go the next step. Why and how was the UN able to perform this function? Why did its role change how the international community reacted to events? Understanding the logic of information transmission helps address these questions and explain why the United States chose an IO-based strategy.

The 1990-91 Persian Gulf conflict is an ideal case for assessing the arguments presented here. Because the episode involves an extremely powerful state using military force against a much weaker one, it represents an unlikely case for showing the importance of institutional involvement. The opportunity costs of using institutions are higher for powerful states - they have more to lose by ceding control. U.S. efforts to gain Security Council support have indeed been rebuffed on multiple occasions, a reflection of the body's diverse interests, its supermajority voting rules, and the veto power of the permanent members, who frequently have divergent preferences. ${ }^{44}$ Looking at a case where the most powerful state turns to the most neutral IO should render salient the tradeoffs and causal mechanisms identified in my theoretical argument.

\section{Motivation and International Political Costs}

In military terms, the Gulf War was remarkably decisive. The vast majority of the forces and equipment were American, and in fact the coalition proved to be a significant burden. ${ }^{45}$ As President George Bush and his advisors confirm, they were primarily seeking political advantages, not military ones, in turning to the UN. ${ }^{46}$ Security Council consent was viewed as critical for avoiding some specific costs that unilateral coercion might generate, such as increased anti-American terrorism. ${ }^{47}$ Relations were perceived to be at stake with other influential states, such as the Soviet Union, and with smaller nations that had come to abhor U.S. intervention in the developing world. ${ }^{48}$ These decisions were motivated instrumentally and not by adherence to multilateralist norms. As one Bush administration official conceded, efforts to gain UN support "did not flow from lofty principles of international unity." 49

In the end, the United States suffered no serious diplomatic setbacks as a result of the war. The political success of U.S. efforts was reflected in the widespread support it achieved, summarized in Table 2. Almost forty countries contributed personnel to the coalition, and more than twenty provided military hardware. Finan-

44. Voeten 2001.

45. See Bush and Scowcroft 1998, 342; Dunnigan and Bay 1992.

46. See Bush and Scowcroft 1998, 356, 385; Haass 1994, 33.

47. Author's interview with a former member of the National Security Council, Washington, D.C., 17 May 1999.

48. See Baker 1995, 281; Bush and Scowcroft 1998, 352.

49. New York Times, 30 August 1990, A1. 
TABLE 2. International support of military intervention against Iraq

\begin{tabular}{|c|c|c|c|}
\hline Country & $\begin{array}{l}\text { Military and/or } \\
\text { medical personnel }\end{array}$ & $\begin{array}{l}\text { Military } \\
\text { equipment }\end{array}$ & $\begin{array}{l}\text { Contributions to } \\
\text { U.S. and U.K. } \\
\text { (in millions of } \\
\text { dollars or pounds) }\end{array}$ \\
\hline 1. Argentina & $\mathrm{X}$ & $\mathrm{X}$ & \\
\hline 2. Australia & $\mathrm{X}$ & $X$ & \\
\hline 3. Bahrain & $\mathrm{X}$ & & \\
\hline 4. Bangladesh & $X$ & & \\
\hline 5. Belgium & $\mathrm{X}$ & $\mathrm{X}$ & $£ 15$ \\
\hline 6. Bulgaria & $X^{1}$ & & \\
\hline 7. Canada & $\mathrm{X}$ & $X$ & \\
\hline 8. Czechoslovakia & $\mathrm{X}$ & $\mathrm{X}$ & \\
\hline 9. Denmark & $\mathrm{X}$ & $\mathrm{X}$ & $£ 8$ \\
\hline 10. Egypt & $\mathrm{X}$ & $X$ & \\
\hline 11. France & $\mathrm{X}$ & $\mathrm{X}$ & \\
\hline 12. Germany & $\mathrm{X}$ & $\mathrm{X}$ & $\$ 6,455 / £ 275$ \\
\hline 13. Greece & $\mathrm{X}$ & $X$ & \\
\hline 14. Honduras & $\mathrm{X}^{1}$ & & \\
\hline 15. Hungary & $\mathrm{X}$ & & \\
\hline 16. Israel & & $\mathrm{X}$ & \\
\hline 17. Italy & $\mathrm{X}$ & $\mathrm{X}$ & \\
\hline 18. Japan & & & $\$ 10,012 / £ 183$ \\
\hline 19. Korea, Republic of & $\mathrm{X}$ & & $\$ 251 / £ 16$ \\
\hline 20. Kuwait & $\mathrm{X}$ & $\mathrm{X}$ & $\$ 16,058 / £ 660$ \\
\hline 21. Morocco & $\mathrm{X}$ & & \\
\hline 22. Netherlands & $\mathrm{X}$ & $\mathrm{X}$ & \\
\hline 23. New Zealand & $\mathrm{X}$ & & \\
\hline 24. Niger & $\mathrm{X}$ & & \\
\hline 25. Norway & $\mathrm{X}$ & $\mathrm{X}$ & \\
\hline 26. Oman & $\mathrm{X}$ & & \\
\hline 27. Pakistan & $\mathrm{X}$ & & \\
\hline 28. Philippines & $\mathrm{X}$ & & \\
\hline 29. Poland & $X$ & $X$ & \\
\hline 30. Portugal & $\mathrm{X}$ & $\mathrm{X}$ & \\
\hline 31. Qatar & $\mathrm{X}$ & $\mathrm{X}$ & \\
\hline 32. Romania & $\mathrm{X}$ & & \\
\hline 33. Saudi Arabia & $\mathrm{X}$ & $\mathrm{X}$ & $\$ 16,839 / £ 580$ \\
\hline 34. Senegal & $\mathrm{X}$ & & \\
\hline 35. Sierra Leone & $\mathrm{X}$ & & \\
\hline 36. Spain & $\mathrm{X}$ & & \\
\hline 37. Syria & $\mathrm{X}$ & $\mathrm{X}$ & \\
\hline 38. Turkey & $\mathrm{X}$ & & \\
\hline 39. United Arab Emirates & $\mathrm{X}$ & & $\$ 4,088 / £ 275$ \\
\hline 40. United Kingdom & $\mathrm{X}$ & $\mathrm{X}$ & \\
\hline
\end{tabular}

Note: Offered troops but turned away for logistical reasons.

Sources: Freedman and Karsh 1993, 361; Lake 1999, 209-10; Matthews 1993, 314-15; and Terasawa and Gates 1993. 
cial contributions of $\$ 54$ billion were also made to the United States, mostly from Saudi Arabia, Kuwait, the United Arab Emirates, Japan, and Germany.

But perhaps the same third-party states that supported the U.S.-led operation would have done so regardless of any UN involvement. There may even be endogeneity: UN approval may have been a result rather than cause of widespread international support. This argument can be rejected for two reasons. First, most states that ultimately supported the intervention were deeply torn initially and through much of the prewar period. Most Arabs loathed the idea of Western troops entering the region, and some saw merit in Iraqi leader Saddam Hussein's accusations against Kuwait. Even King Fahd of Saudi Arabia, facing the most immediate threat of continued Iraqi aggression, strenuously resisted U.S. assistance. ${ }^{50}$ Non-Arab leaders were no more eager. Soviet leader Mikhail Gorbachev faced strong domestic opposition to supporting the United States and insisted through the end of October that the use of force was unacceptable. Others, such as France and Turkey, faced substantial losses from the cessation of trade and the oil embargo.

By November, with the exception of the United Kingdom, every European and Arab member of the emerging coalition, as well as Canada and the Soviet Union, had made Security Council approval a condition of their support for offensive action. ${ }^{51}$ Without such a resolution, continued sanctions and diplomacy were almost universally preferred. In sum, support of U.S. action in the Gulf War was by no means a foregone conclusion, and Security Council endorsement was a key variable in determining reactions to the policy.

\section{Signaling Intentions to State Leaders}

As the world's only superpower contemplated the use of military coercion, the international community was clearly concerned with U.S. intentions. Goals that included overthrowing Saddam, occupying Iraq or establishing an indefinite, largescale military presence were viewed as threats to third-party interests. Goals limited to restoring the pre-invasion status quo, by contrast, were generally viewed as benign.

Gulf states had a genuine concern for their sovereignty and the encroachment of U.S. military influence. ${ }^{52}$ Arab leaders reacted with fear and suspicion of ulterior motives, including a desire to exploit local resources and establish political dominance in the region. ${ }^{53}$ War aims that included toppling Saddam were entirely

50. Heikal 1992, 213.

51. See New York Times, 16 November 1990, A12; Toronto Star, 13 November 1990, A1; and Washington Post, 9 November 1990, A1.

52. Those states most immediately affected, such as Kuwait and Saudi Arabia, were effectively being asked to submit to protectorate status for the duration of the American military presence. Lake 1999, 235-36.

53. Khalidi 1991, 167. For example, Saudi Arabia's King Fahd suspected the United States of wanting to establish additional permanent military bases. Heikal 1992, 212. 
unacceptable to these regimes. Those outside the region were worried about the precedent being set and with their own political influence in the Gulf. European governments viewed initial U.S. reactions to Iraq's invasion as hasty and aggressive. For example, the French hoped that Iraq would not be unduly weakened so that their trading relationship could be preserved, and France's defense minister warned that U.S. "hegemonic temptations" would threaten France's "freedom of choice" in the Middle East. ${ }^{54}$ After losing Europe to the West, the Soviets had political and strategic apprehensions over U.S. motivations and long-term goals in the Gulf, a Cold War battleground. ${ }^{55}$ As one foreign ministry official complained early in the standoff, "There are no guarantees that the United States will leave Saudi Arabia after the crisis is over." ${ }^{56}$ For most leaders, U.S. muscle flexing was inherently threatening and undesirable.

The United States thus faced the problem of signaling its intentions. As Hypothesis 1 suggests, by channeling its coercion through the Security Council, the United States assumed costs that helped signal its limited goals. Aside from the operational difficulties that arose from putting together a multinational force, U.S. political and military leaders faced a number of real costs in the form of delays, limits on policy autonomy, and additional scrutiny. The Bush administration was constrained by the methodical decision-making process and influence costs that resulted from seeking approval during each phase. As one senior administration official lamented, "When you try to bring people on board, you have to listen to them." 57

At two stages in particular U.S. policies were delayed and adjusted to mollify the Security Council: the decision to enforce the initial embargo on Iraq and the decision to launch the military operation called Desert Storm. Resolution 661, passed on 6 August 1990, imposed a trade embargo on Iraq. Though the United States-and the United Kingdom, whose navy was also patrolling the Gulf-was willing and able from the start to enforce the embargo, ships were allowed to pass through the blockade for weeks. Scowcroft describes the dilemma:

The question was, do we move unilaterally to stop them, or do we wait and try to get additional authority from the UN? We had lengthy discussions with the British about it and of course [British Prime Minister Margaret] Thatcher said go after the ships.... [U.S. Secretary of State James] Baker was insistent that we wait. He convinced the President we would lose the Soviets (who were still adamantly opposed to using force) and perhaps the chance for a positive vote in the Security Council on enforcement if we went ahead unilaterally. ${ }^{58}$

54. Le Monde, 31 January 1991, 6.

55. See Alexandrova 1991, 233-34; Freedman and Karsh 1993, 162-65.

56. New York Times, 31 August 1990, A13. During a meeting with Bush on September 9, Gorbachev sought assurances that the United States intended to withdraw its forces from the region as soon as possible following the conflict. News Conference 1990, 1345.

57. Newsweek, 1 October 1990, 20.

58. Bush and Scowcroft 1998, 351-52. 
U.S. National Security Advisor Colin Powell and Defense Secretary Richard Cheney agreed that, for political reasons, they should wait for UN approval. ${ }^{59}$

The French and Soviets worried that enforcement action would provoke retaliation by Iraq and thereby trigger war, and they argued that Resolution 661 alone could not be used as authorization. The Soviets were the major obstacle, delaying by at least ten days a new resolution approving force. ${ }^{60}$ Ultimately, approval came on 25 August in the form of Resolution 665, which authorized the use of force to disable ships that refused to stop for inspection.

Waiting for UN endorsement to enforce the embargo was costly, beyond the fact that supplies were reaching Iraq in the meantime. To begin with, there was a credibility issue, as Freedman and Karsh point out: "Here was the first potential use of force and the United States dare not back down lest it appear a 'paper tiger.' If it hesitated, inevitable questions would be raised about its readiness to stay the course." ${ }^{61}$ Moreover, waiting for another resolution raised the prospect of lost flexibility. Seeking further approval, Thatcher complained, would "tie our hands unacceptably." 62 This fear proved well founded. China, the Soviet Union, and France insisted on strict wording for the resolution that did not simply state that "minimum use of force" could be used-the Americans' preferred language, which had almost unlimited interpretations - but rather spelled out that only measures "commensurate to the specific circumstances as may be necessary" could be employed. There is evidence that France and China explicitly sought Resolution 665 as a way to stall and impose limits on the use of force. ${ }^{63}$ As one British journalist noted at the time, "the Soviet Union wanted to get as many constraints as possible on U.S. military action in the Gulf." 64

For U.S. decision makers, the next great debate-and delay-was over the launching of Desert Storm. Thatcher again warned Bush that going back to the UN would constraint them unduly. In seeking a further resolution, she argued, "We risk amendments," therefore it was preferable to "go to war on our own terms." ${ }^{65}$ The information rationale suggests that it was precisely the prospect of constraint and even outright rejection, a function of the Security Council's neutrality, that made going to the UN so politically important.

In the end, the United States waited four months from the invasion until Resolution 678 authorized the use of force. Considerable diplomacy and consultations took place before the United States could even propose language for a resolution, and Security Council voting rules (the dual obstacles of supermajority and the

59. Woodward 1991, 284.

60. Toronto Star, 25 August 1990, A1.

61. Freedman and Karsh 1993, 147.

62. Thatcher $1993,821$.

63. For more on the passage of Resolution 665, see Freedman and Karsh 1993, 143-50.

64. Independent, 27 August 1990, 7.

65. Bush and Scowcroft 1998, 384. 
veto) gave other governments considerable leverage. A senior Bush administration official described the difficult process of garnering the necessary votes: "We have an idea of the kind of resolution we'd like. But that's very different than presenting countries with draft language of a proposal that you are going to consider tabling in the council.... Each country is one vote; you need nine votes to pass a resolution, and some are in different places on this." ${ }^{66}$ Indeed, the strategy of other Security Council members was to insist on a resolution authorizing force so they could influence the timing and scope of any potential combat. ${ }^{67}$ Baker spent much of the month of November painstakingly organizing support by soliciting input and offering concessions and side-payments-efforts that would have been largely unnecessary outside the context of an IO.

The Soviets in particular pushed for more moderate language and insisted on more time for diplomacy throughout the month. Even when a date for a Security Council vote was settled, while the United States hoped to set a relatively prompt deadline for Iraqi withdrawal, the Soviet Union and France insisted on a "pause for peace" as a condition of the resolution's passage. The Soviets asked for a 31 January 1991 deadline; the French compromise of 15 January was selected. The very idea of an "announced" war, it should be noted, represented a constraint, as U.S. planners had preferred a more flexible approach. ${ }^{68}$

Delay was costly for three reasons. First, it allowed Saddam to prepare for hostilities and required the size of the Allied force to be augmented accordingly. Bush worried in early January that the United States would pay a high price in lives by allowing the Iraqi army to dig in. ${ }^{69}$ Part of this waiting period was needed to move troops and equipment into position, but its duration exceeded by weeks the optimal length of time. Another potential cost of delay came in the domestic political realm. The U.S. antiwar movement developed momentum in January, including within Congress, and thus delay was risky for Bush from a political standpoint. ${ }^{70}$ Finally, some feared it would be hard to maintain a coalition over time as diplomacy and the fading memory of Iraq's transgression rendered the military option less appealing, thus making delay risky. ${ }^{71}$

The wait was valuable politically: it satisfied European countries that hoped to further explore diplomatic means and allowed Arab leaders to investigate "Arab solutions." It also showed that the United States was willing to be constrained and to accommodate the interests of others. Reflecting the success of this benign sig-

66. Quoted in Washington Post, 16 November 1990, A21.

67. New York Times, 11 November 1990, A1.

68. Ibid., 14 November 1990, A1.

69. Radio Address to the Nation on the Persian Gulf Crisis, 5 January 1991. Available at 〈http:// bushlibrary.tamu.edu/research/papers/1991/91010500.html $\rangle$. Accessed 1 September 2005.

70. Mueller 1994, 59-60.

71. This argument was made most prominently in a Washington Post editorial by Henry Kissinger. Washington Post, 11 November 1991. 
nal, Gorbachev told Baker in early November, "[We] have noticed that in this situation you are not losing your cool."72

When the United States, with operation Desert Storm underway, declared a ceasefire on 28 February, reactions were mixed. The abrupt end and Saddam's continued rule sparked accusations that the coalition had not truly succeeded, and within months of the war Bush's popularity ratings had plummeted. Early in the episode, various options, including invasion and the removal of Saddam, were on the table. The IO-based strategy required that these more ambitious goals be removed to generate consensus in the Security Council. Bush knew it would be costly to accept and adhere to a limited UN mandate, as prewar polls showed a strong public desire to remove Saddam. ${ }^{73}$ Yet U.S. leaders remained committed to limited goals partly because they felt constrained by the mandate and did not want to risk forfeiting the attendant political benefits. According to Bush, "I firmly believed we should not march into Baghdad. Our stated mission, as codified in UN resolutions, was a simple one-end the aggression, knock Iraq's forces out of Kuwait, and restore Kuwait's leaders. To occupy Iraq ... would have taken us way beyond the imprimatur of international law bestowed by the resolutions." ${ }^{74}$ While other factors were involved, such as the costs of an occupation and fear of a regional power vacuum, the president's son and future president, George W. Bush, and Powell both confirmed that the senior Bush felt constrained by the resolutions to do no more than force Saddam from Kuwait. ${ }^{75}$

Relinquishing some decision making to the Security Council allowed the United States to credibly signal that it preferred a limited operation (restoration of the pre-invasion status quo) and was not motivated by hidden ambitions. U.S. assertions before the Security Council that it had limited goals consistent with the UN mandate ${ }^{76}$ were more credible than Iraqi arguments that the policy represented an effort to impose domination on the region. A day after the war began, the Egyptian foreign minister expressed his confidence that it "does not have the purpose of destroying Iraq but of liberating Kuwait." 77 This increased confidence regarding U.S. intentions made leaders more willing to offer support.

\section{Transmitting Policy Information to Foreign Publics}

From the time U.S. troops began arriving to defend Saudi Arabia, leaders throughout the international community faced tough domestic political questions in deciding whether to support a U.S.-led invasion. Potential coalition governments knew that IO approval would help them "sell" support of the war to their domestic audi-

72. Quoted in Aldrich-Moodie 1998, 18.

73. Mueller 1994, 41-42, 54.

74. Bush and Scowcroft 1998, 464.

75. See Woodward 2002, 329; Powell 1995, 521.

76. UN Doc. S/22090, 17 January 1991.

77. UN Doc. S/22113, 18 January 1991. 
ences, and this provided additional motivation to push for a Security Councilbased approach. For their part, U.S. policymakers clearly had foreign publics in mind when they chose to work through the Security Council. Scowcroft believed that the UN "could provide a cloak of acceptability to our efforts and mobilize world opinion behind the principles we wished to project." 78 Hypothesis 2 captures this as a process of information transmission: IO approval serves as an information shortcut for publics as they assess whether intervention offers collective international benefits and is worthy of their government's support.

When they address domestic politics, scholars studying the role of IOs in U.S. military intervention typically focus on the audience at home. ${ }^{79}$ By focusing instead on the role of foreign publics, I am not arguing that politics in the United States were unimportant-multilateralism benefited the Bush administration in terms of public opinion and the debate in Congress. Nevertheless, decision makers were not primarily motivated by political concerns at home when they turned to the $\mathrm{UN}$. Bush was willing to proceed to war without majority approval and without a favorable vote in Congress. ${ }^{80}$ Moreover, recent history shows that IO endorsements have a mixed effect on U.S. public opinion of interventions; indeed, presidents are often viewed as being "tough" and effective when they proceed unilaterally. ${ }^{81}$ Despite an abstract preference for multilateralism, Americans tend to rally behind their leaders regardless of the approach taken.

In the 1990-91 case, many governments, having concluded that it might be in their interest to support U.S. action, initially felt constrained by their publics from doing so. Domestic audiences were most skeptical in the Arab and Muslim world, where Western military intervention was an especially sensitive issue. Following the Iraqi invasion, no Arab regime dared to call publicly for U.S. assistance; even Kuwait's desperate call for international help was qualified with an explicit preference for an "Arab solution." A study of Arab public opinion during the Gulf War concludes that Arab governments, though autocratic, were constrained by domestic attitudes and calibrated their policies accordingly. ${ }^{82}$

The domestic political challenges facing leaders outside the region were qualitatively different but also important. As one newspaper characterized the situation in Europe in late August 1990, while condemnation of Iraq was unanimous, "domestic political difficulties and wariness about jumping aboard a U.S. bandwagon are still causing division on the issue of military action outside a UN umbrella." ${ }^{83}$ Most Europeans were skeptical of a military solution and opposed toeing the U.S. line. To the east, Gorbachev faced myriad domestic challenges, leading him to insist that any decisions on military action be taken by the Security Council. In

78. Bush and Scowcroft 1998, 491.

79. See Cortell and Davis 1996; Schultz 2003; Chapman and Reiter 2004.

80. See Powell 1995, 499; Bush and Scowcroft 1998, 446.

81. Luck 2002.

82. Pollock 1993.

83. Independent, 25 August 1990, 7. 
the wake of Afghanistan, it was difficult to generate public enthusiasm for an overseas intervention, and there was pressure from the right and the military to dissociate Soviet policy from the appearance of U.S. influence. ${ }^{84}$ Speaking to Baker, Gorbachev put a fine point on the problem: "You are asking the Soviet Union to approve the use of American force against a long-time ally of the Soviet Union." 85 Diplomatic efforts by the United States were frustrated as much by domestic opposition as by any international factor.

These domestic political barriers were largely removed as a result of the UN's involvement. As U.S. policy toward Iraq became increasingly enmeshed in the Council, domestic opposition around the world was diminished to the point where few governments felt constrained. Despite lingering resentment, fears of upheaval in the "Arab street" were not realized. Governments with Muslim populations saw a UN-based approach to Iraq as key to overcoming domestic barriers to the intervention. Egypt and Turkey, for example, strongly urged Baker to seek Security Council resolutions "to protect themselves against domestic political opposition." 86 It is interesting to note that even those governments that supported Saddam throughout most of the crisis still endorsed UN sanctions and welcomed UN involvement. ${ }^{87}$ While support of-and subordination to-the United States was distasteful, support of the UN was politically acceptable and indicated to publics that collective interests were at stake.

Once Arab leaders decided that the risks of a more powerful Iraq were too great and that Western intervention was sufficiently unthreatening, they targeted their publics with a "coordinated information campaign" centered around the multilateral nature of the intervention. ${ }^{88} \mathrm{UN}$ cover allowed Egyptian President Hosni Mubarak to argue to his citizens that Saddam "is one man against the world," and his pro-intervention stance was ultimately supported by a clear majority of the population. ${ }^{89}$ Gorbachev also maintained enough domestic support (albeit barely) by pointing to Security Council approval and by framing the operation to the public as a collective mission. The UN became the rhetorical focal point of Soviet policy. A foreign ministry spokesperson justified his country's involvement by declaring, "We are for the Security Council to tackle this most urgent issue now." 90 In a sixteen-sentence joint statement released by Gorbachev and Bush on 9 September, there were seven references to the UN or the Security Council. Calling on "the entire world community," the two leaders insisted that "Nothing short of the complete implementation of the United Nations Security Council Resolutions is

84. See Alexandrova 1991, 233; Fuller 1991, 58; Shevardnadze 1991, 202.

85. Quoted in Freedman and Karsh 1993, 231.

86. New York Times, 2 December 1990, A3.

87. See Lesch 1991, 36; Khalidi 1991, 162-63.

88. Telhami 1993, 194.

89. See New York Times, 8 November 1991, A1; and "Poll Shows Majority Egyptians Back Government Policy," Xinhua Overseas News Service, 20 January 1991 (accessed via Lexis-Nexis), citing a poll conducted by the American Chamber of Commerce in Cairo.

90. Quoted in Freedman and Karsh 1993, 125. 
acceptable." ${ }^{91}$ Gorbachev understood that his domestic audience would be influenced by knowledge of the UN's role. As one observer notes, the UN umbrella "made it possible for the Soviet Union to support the anti-Iraq coalition without any explicit connection to the United States." 92

Various Western leaders also relied on the UN to make support politically possible. France would not have participated outside the aegis of the UN. Though French President François Mitterrand felt that Article 51 was sufficient from a legal perspective, he knew it could not justify military coercion to his domestic audience. "Article 51 doesn't mind public opinion," he explained to Baker. "Fiftyfive million French people are not international lawyers. We need that resolution [to authorize the use of force] to ensure the consequences it will entail." ${ }^{93}$ Germany and Japan both faced cultural and constitutional barriers to supporting military action. In order to justify their financial support, their governments framed the intervention as a collective effort under the UN's umbrella. ${ }^{94}$ For publics around the world, Security Council resolutions "converted the United States policy of military coercion against Iraq . . into a United Nations policy of military coercion." 95 That leaders around the world were so eager to stress UN involvement suggests that this information was received and viewed as important by their constituents.

The details of leaders' framing strategies are also consistent with the information rationale for Security Council influence. Beyond references to UN involvement, in statements designed for public consumption U.S. and third-party leaders stressed certain characteristics of the Security Council to emphasize its neutrality, namely that its membership was heterogeneous and representative of the international community. Baker understood the political importance of framing the conflict as a collective effort in the collective interest: "We believed it was imperative to keep the debate from turning into an Iraq-versus-the-United States confrontation, which would have made it more difficult to build and maintain a coalition." ${ }^{96}$ As evidence that global interests were at stake, U.S. leaders pointed to the votes of the Security Council. "These goals are not our own," Bush proclaimed. "They have been endorsed by the United Nations Security Council." 97 Baker portrayed Resolution 678 as representing "the will of the international community." 98 The composition of the Security Council-the ten rotating members at the time were Canada, Colombia, Ethiopia, Finland, the Ivory Coast, Cuba, Malaysia, Romania, Yemen, and Zaire - gave its endorsement considerable credibility. Its hetero-

91. Bush and Gorbachev 1990.

92. Friedman 1991, 50.

93. Baker 1995, 315 .

94. See Daily Telegraph, 10 September 1990, 12; Purrington and A. K. 1991, 318.

95. Matthews 1993, 76.

96. Baker 1995, 278.

97. U.S. Congress 1991, 25. See also Bush 1990, 57.

98. Statement of January 9, 1991, reprinted in Sifry and Cerf 1991, 172-73. 
geneity allowed Bush to argue reasonably in his 1991 State of the Union speech that "diverse nations are drawn together in common cause."

Leaders of other countries also stressed the neutrality of the Security Council in their public statements. At a 9 September press conference, Gorbachev referred to "efforts being taken by the international community working together within the Security Council." 99 In a speech before the House of Commons following the passage of Resolution 678, Canadian External Affairs Minister Joe Clark summarized the situation facing Iraq: "It is now up to Saddam Hussein to determine whether the international community will have to use the authority of the UN to achieve our collective goal through the use of force." ${ }^{100}$ Referring more directly to the informative properties of the Security Council, French Foreign Minister Roland Dumas described the body as "an expression of the community of nations as a whole and also of all that community's diversity." ${ }^{101}$ During Security Council meetings throughout the episode, representatives repeatedly referred to the Security Council and its resolutions as representing the "voice" and "will" of the international community. ${ }^{102}$

In other words, leaders were careful to stress the institutional characteristics that render institutional agents-from legislative committees to IOs-most informative: a heterogeneous and representative membership. While public statements explain little about what motivates speakers themselves, these statements are potentially revealing with respect to their intended audience. Based on the two assumptions identified in the previous section - that the information received by publics about foreign affairs derives largely from their leaders, and that leaders have some understanding of what information is persuasive to their publics-this lends further support to Hypothesis 2.

Finally, a useful comparison of international public opinion can be made to the 2003 Iraq war, conducted with no IO mandate. While roughly 70 percent of Western Europeans supported intervention in the first Gulf War, only 19 percent of Europeans polled by EOS Gallup Europe in January 2003 supported the second. ${ }^{103} \mathrm{UN}$ authorization was a key variable. When asked if the United States should intervene militarily in Iraq without UN approval, a plurality in only one European country (Slovakia) out of thirty agreed. When asked if their country

99. News Conference 1990, 1347.

100. Toronto Star, 29 November 1990, A1.

101. UN Doc. S/PV.2943, 25 September 1990, 33.

102. For examples of such statements by representatives of Canada, Ethiopia, Finland, France, the United Kingdom, Malaysia, Romania, the Soviet Union, and Zaire at key junctures of the Iraq episode, see the following UN documents: 2/PV.2934, 9 August 1990, 13-15, 16, 21; S/PV.2938, 25 August 1990, 33, 38, 48; S/PV.2943, 25 September 1990, 33, 46, 66, 74; and S/PV.2963, 29 November 1990, 79. It should be noted that statements made before the Security Council are carefully crafted and intended for public consumption, not for active deliberation or debate.

103. Washington Post, 25 October 1990, A31 (summarizing a Gallup poll conducted in October 1990); EOS Gallup Europe, "International Crisis Survey.” Available at (www.eosgallupeurope.com/ int_survey $\rangle$. Accessed 4 June 2004. 
should participate in a military intervention with Security Council approval, the number of pluralities jumps to fifteen. A Gallup International poll also conducted in January 2003 showed that few populations were in favor of war. When asked if their country should support a war, majorities in only the United States and Australia responded positively; in the remaining thirty-seven countries there was no majority support. The prospect of UN authorization, however, raised favorable attitudes toward the war by 30 to 50 percent in most EU countries, and by 46 percent in Canada, 56 percent in Australia, and 29 percent in India. ${ }^{104}$ As noted above in the discussion of Hypothesis 2, publics were highly skeptical of whether war was justified and would provide collective benefits. Absent UN approval, they had more negative views of the policy and generally did not find the stated rationale to be credible.

In both wars, even when government leaders had decided that supporting the intervention was in their country's interest, many faced domestic opposition. The Security Council's imprimatur was the most powerful tool for convincing these publics that the coercive policy was reasonable and worthy of support. As one Turkish diplomat notes, contrasting the 2003 Iraq war with the first, "[A] resolution gives us something to work with domestically; we just didn't have that in the second case." 105 Those leaders who did support the "coalition of the willing" were in some cases punished afterwards by their electorates.

I have offered indirect but suggestive evidence that channeling coercion through the UN during the 1990-91 episode served to transmit policy-relevant information to publics around the world, thus removing a domestic political barrier to third-party support. Many leaders were constrained by domestic politics from supporting the United States initially, but these constraints largely disappeared as the policy became firmly entrenched in the Security Council.

\section{Information versus Legitimacy}

My empirical discussion has focused largely on providing confirming evidence for my information argument. I have briefly considered specific alternative explanations (domestic politics in the United States, burden sharing, and endogeneity) for the Security Council's role but I have not directly addressed the most prominent theoretical alternative: that the observed "legitimation effect" of IO approval rests on the importance of legitimacy. Legitimacy is fungible and can be transferred from an institutional holder to another actor. ${ }^{106}$ Thus it is possible that the

104. Iraq Poll 2003. Available at 〈http://www.gallup-international.com/ContentFiles/ survey.asp?id=10 . Accessed 28 September 2005.

105. Author's interview with a Turkish diplomat, New York, 13 November 2003. The interviewee was confident that UN authorization of the 2003 intervention would have swayed public opinion sufficiently to allow more active support, such as providing a base of operations for U.S. ground troops.

106. Hurd 2002. 
international community views IO approval as conferring legitimacy on state actions, appealing to an internalized norm that legitimate behavior is appropriate and thus worthy of support. This legitimacy logic arguably represents the conventional wisdom for understanding the political effects of IO approval.

It is difficult to disentangle these distinct logics - rational information transmission versus normative legitimacy_-since their broad effects are observationally equivalent. In both cases IO approval leads to more international support. On closer inspection, however, there are distinct observable implications for both mechanisms that can help one assess their relative explanatory power in a given case. I consider three sources of evidence in this section: the design features of the Security Council, the behavior of foreign leaders, and the attitudes of publics.

The legitimacy and information rationales make different predictions about what sorts of institutional design features generate the greatest political effect. I have noted the consensus among scholars and practitioners that the UN, especially the Security Council, is a uniquely powerful legitimizer of state policies. Leaders covet its approval over regional endorsements and publics are more likely to support the use of force endorsed by the Security Council as compared to regional IOs or allied coalitions. ${ }^{107}$ So one might usefully ask whether the Security Council's design is more consistent with an informative institution or with a legitimate institution. I have offered evidence that the heterogeneity and representative nature of its membership make it a neutral and thus credible information provider to the international community. By contrast, the Security Council has few features of a legitimate institution or of an institution that creates legitimate rules. For example, it lacks the requirements of procedural legitimacy, such as transparency, democracy and accountability, and its decisions are inconsistent and based on ambiguous law. ${ }^{108}$ It is not well designed to confer legitimacy through its resolutions.

Moreover, if legitimacy is operating, one would expect smaller IOs with more homogeneous memberships to be most influential in generating support. Constructivist scholars show that norms and socialization processes matter most in more intimate, "in-group" settings. ${ }^{109}$ Hurd and Franck both argue that legitimacy can only operate in the context of a coherent social community. ${ }^{110}$ One would thus expect common standards of legitimacy to be strongest among countries that share values and norms, such as within NATO or the OAS. ${ }^{111}$ The Security Council, by contrast, has a diverse, worldwide membership - and one with no shared culture or values. ${ }^{112}$ Yet its endorsements matter more in practice. In short, Security Council features are more consistent with an information function than with a legiti-

107. Asmus, Everts, and Isernia 2004, 10-13 (analyzing public opinion data from the Transatlantic Trends 2003 survey).

108. See Schachter 1989; Voeten 2005.

109. See Checkel 2001; Johnston 2001.

110. See Franck 1990; Hurd 1999.

111. Schimmelfennig (1998/1999) makes precisely this argument.

112. Johnstone 2003, 456. 
macy function, and the legitimacy argument does not account for the Security Council's unique ability among IOs to generate international support.

Turning to the behavior of leaders, I have already shown that U.S. policymakers, in seeking IO approval, were motivated instrumentally and not by an internalized desire to act appropriately. But perhaps foreign leaders were motivated differently. If legitimacy is operating, one should see leaders supporting the policy because it is the "right" thing to do and not because of a cost-benefit assessment of self-interest. ${ }^{113}$ What one sees in fact is that leaders such as Gorbachev, Mitterrand, and Fahd were calculating the effects of intervention on their domestic and international positions, as a function of U.S. intentions and their own publics' reactions. Moreover, many leaders sought to extract side-payments in return for their support or were motivated by a desire to share in the spoils of the intervention in the form of increased regional influence. ${ }^{114}$ As Johnston notes, such material motivations are inconsistent with behavior driven by social norms. ${ }^{115}$

It is perhaps more likely that foreign publics reacted to Security Council approval through legitimacy rather than information mechanisms. Two sources of evidence suggest this is not the case. First, while Security Council approval led to more international public support for the U.S.-led intervention, this support did not translate into a commensurate desire to actively participate in the intervention. Arguably, a normative motivation would be associated with a desire to participate in what is perceived as a legitimate action, just as legitimate rules inspire a felt obligation to comply. In October 1990, while 73 percent of French approved of Bush sending troops to Saudi Arabia and 75 percent approved the use of force, only 42 percent of those polled in early November approved of French participation. On the eve of war, while support for the use of force was high, 57 percent were opposed to French military involvement. Similarly, while most Spaniards supported Bush and favored the use of force, 60 percent were against their government's move to send troops and warships. Three-fifths of Italians favored the use of force and approved of Bush's actions, but only a third favored sending Italian combat troops. ${ }^{116}$ So while there was support for the policy and the consequences it would entail, there was much less desire to participate. This behavior-support coupled with free-riding - is more consistent with a rationalist-materialist logic than with a normative one. Publics should want and even feel obligated to participate in an action deemed legitimate.

The second source of evidence again involves the public statements and framing strategies of leaders. If the legitimacy conferred by IO approval is important

113. Hurd 1999, 387-88.

114. See Bennett, Lepgold, and Unger 1994, 72-23; Lake 1999, 245-46.

115. Johnston 2001, 510.

116. See various polls conducted by Gallup and Sofres-Le Figaro, cited in The Times, 19 October 1990; New York Times, 19 October 1990, A10; Index to International Public Opinion 1990-1991, 579_ 80; and Canal Ipsos, 11 February 2003. Available at 〈www.ipsos.fr/CanalIpsos/articles/1067.asp〉. Accessed 1 September 2005. 
to publics, we should see leaders framing Security Council involvement in legitimacy terms. I analyze the content of the four Security Council resolution debates most closely associated with the question of coercion during the Gulf War conflict: the 6 August discussion of Resolution 660, imposing an economic embargo; the 25 August discussion of Resolution 665, authorizing enforcement of the embargo; the 25 September discussion of Resolution 670, extending and strengthening the blockade; and the 29 November discussion of Resolution 678, authorizing force. ${ }^{117}$

While there is considerable discussion of the informative properties of the Security Council, as discussed above, there is virtually no mention of its institutional legitimacy or the legitimacy of its resolutions. In 325 pages of transcribed speeches, the terms legitimacy and legitimate are used approvingly to describe the Security Council or its resolutions only once (by the Soviet Union on 25 September). Ironically, the only representatives who address the issue of Security Council legitimacy are from Cuba and Iraq - and they do so to condemn its actions as illegitimate. The question of legitimacy was certainly on the minds of Security Council representatives, as they referred frequently to the legitimacy of the Kuwaiti government in exile. But despite their preoccupation with the concept, in these lengthy and carefully crafted public speeches there was seemingly no concern with stressing the legitimacy of the Security Council. This suggests that their respective publics were not motivated primarily by legitimacy concerns and were not swayed by Security Council approval through legitimacy-based mechanisms.

This section by no means provides an exhaustive competitive test between these two theoretical perspectives, information versus legitimacy. I have offered several observable implications of the legitimacy argument involving institutional design, the behavior of leaders, and the behavior of publics, and in each case there are reasons to question whether IO approval confers legitimacy per se on state actions. Nevertheless, especially with respect to publics, it is quite likely that actors are motivated by both rationalist and normative concerns, and any complete theoretical account of the legitimation effect should include both components. ${ }^{118}$

\section{Conclusion}

Understanding why even the most powerful states subject themselves to the constraints of international institutions remains among the most intriguing theoretical puzzles for IR scholars. I explore the theoretical intersection of power and institutions by asking why states often channel coercive policies through IOs. This question has typically been answered by pointing to the legitimation effect of IO approval, however the causal mechanisms of this phenomenon are not well under-

117. The relevant UN documents are S/PV.2933, S/PV.2938, S/PV.2943, and S/PV.2963.

118. For an effort to synthesize these perspectives, see Thompson 2005. 
stood. I provide a largely rationalist theoretical explanation based on the informative properties of institutions as agents of the international community. Formal IOs that are neutral, with heterogeneous and representative memberships, are uniquely capable of providing credible information regarding a coercing state's intentions and the consequences of its policy. Leaders and publics rely on this information when deciding whether to support or oppose the action.

I conduct a detailed case study to uncover the dynamics of information transmission. During the 1990-91 Gulf War, the world's only superpower showed a willingness to cede some control to an IO that was able to independently assess and impose costly constraints on the coercive policy. By working through the Security Council, the United States was able to send information regarding its intentions to other states leaders and to send policy-relevant information to publics abroad. This information increased international support for the intervention, thus explaining the incentives to seek IO approval. A preliminary comparison suggests that legitimacy-based explanations cannot account for the behavior of state leaders or their publics in this case, and fail to explain the unique role of the Security Council as an endorser of military intervention in the contemporary world.

The framework can be extended both theoretically and empirically. I offer a ceteris paribus argument insofar as a state may bypass IOs when the anticipated political costs of action are already low or when there is high sensitivity to the costs of constraint. Elaborating these tradeoffs would help one understand how coercers choose among institutions with different designs and thus different constraints and informative properties. I only begin to address these "forum shopping" issues here. While I have treated institutions themselves as exogenous in my theoretical model and empirics, my argument has implications for the endogenous treatment of institutions. The political advantages of channeling statecraft through IOs helps explain why powerful states create and join these institutions in the first place, and why they design them with certain properties. To further explore the boundaries of the argument, it should be applied to cases of economic and diplomatic coercion as well. While the nature of costs and benefits will change in these settings, the central theoretical insights should apply beyond cases of military intervention.

Finally, a wider range of hypotheses and observable implications should be used to compare the rationalist framework presented here with a norm-based framework based on the importance of legitimacy. More eclectic theorizing and testing will help one "get to the bottom" of the widely observed legitimation function of IOs, an increasingly important phenomenon in international affairs.

\section{References}

Abbott, Kenneth, and Duncan Snidal. 1998. Why States Act Through Formal International Organizations. Journal of Conflict Resolution 42 (1):3-32. 
Aldrich-Moodie, Benjamin. 1998. Negotiating Coalition: Winning Soviet Consent to Resolution 678 Against Iraq. WWS Case Study 1/98. Princeton, N.J.: Woodrow Wilson School of Public and International Affairs.

Alexandrova, Olga. 1991. Soviet Policy in the Gulf Conflict. Aussenpolitik 42 (3):231-240.

Asmus, Ronald, Philip Everts, and Pierangelo Isernia. 2004. Power, War and Public Opinion. Policy Review 123:72-88.

Baker, James (with Thomas DeFrank). 1995. The Politics of Diplomacy: Revolution, War and Peace, 1989-1992. New York: Putnams' Sons.

Bawn, Kathleen. 1995. Political Control Versus Expertise: Congressional Choices about Administrative Procedures. American Political Science Review 89 (1):62-73.

Bayard, Thomas, and Kimberly Elliott. 1994. Reciprocity and Retaliation in U.S. Trade Policy. Washington, D.C.: Institute for International Economics.

Bennett, Andrew, Joseph Lepgold, and Danny Unger. 1994. Burden-Sharing in the Persian Gulf War. International Organization 48 (1):39-75.

Bernhard, William. 1998. A Political Explanation of Variation in Central Bank Independence. American Political Science Review 92 (2):311-27.

Bush, George. 1990. The Persian Gulf: Pursuing Multinational Objectives, August 22. Department of State Dispatch 1 (1):57.

Bush, George, and Mikael Gorbachev. 1990. US-USSR Statement, September 9. Department of State Dispatch 1 (3):92.

Bush, George, and Brent Scowcroft. 1998. A World Transformed. New York: Knopf.

Chapman, Terrence, and Dan Reiter. 2004. The United Nations Security Council and the Rally 'Round the Flag Effect. Journal of Conflict Resolution 48 (6):886-909.

Chayes, Abram, and Antonia Handler Chayes. 1995. The New Sovereignty: Compliance with International Regulatory Agreements. Cambridge, Mass.: Harvard University Press.

Checkel, Jeffrey. 2001. Why Comply? Social Learning and European Identity Change. International Organization 55 (3):553-88.

Claude, Inis. 1966. Collective Legitimization as a Political Function of the United Nations. International Organization 20 (3):367-79.

Cortell, Andrew, and James Davis. 1996. How Do International Institutions Matter? The Domestic Impact of International Rules and Norms. International Studies Quarterly 40 (4):451-78.

Crawford, Vincent, and Joel Sobel. 1982. Strategic Information Transmission. Econometrica 50 (6):1431-51.

Downs, Anthony. 1957. An Economic Theory of Democracy. New York: Harper and Row.

Dunnigan, James, and Austin Bay. 1992. From Shield to Storm: High-Tech Weapons, Military Strategy, and Coalition Warfare in the Persian Gulf. New York: William Morrow.

Epstein, David, and Sharyn O'Halloran. 1999. Delegating Powers: A Transaction Cost Politics Approach to Policy Making under Separate Powers. Cambridge: Cambridge University Press.

Fearon, James. 1994. Domestic Political Audiences and the Escalation of International Disputes. American Political Science Review 88 (3):577-82.

1997. Signaling Foreign Policy Interests: Tying Hands versus Sinking Costs. Journal of Conflict Resolution 41 (1):68-90.

Fenton, Neil. 2004. Understanding the UN Security Council: Coercion or Consent? Burlington, Vt.: Ashgate.

Finnemore, Martha. 1996. Constructing Norms of Humanitarian Intervention. In The Culture of National Security, edited by Peter Katzenstein, 153-85. New York: Columbia University Press.

- 1998. Military Intervention and the Organization of International Politics. In Collective Conflict Management and Changing World Politics, edited by Joseph Lepgold and Thomas Weiss, 181204. Albany: State University of New York Press.

Franck, Thomas. 1990. The Power of Legitimacy Among Nations. New York: Oxford University Press. Freedman, Lawrence, and Efraim Karsh. 1993. The Gulf Conflict, 1990-1991. Princeton, N.J.: Princeton University Press. 
Friedman, Norman. 1991. Desert Victory: The War for Kuwait. Annapolis, Md.: Naval Institute Press. Fuller, Graham. 1991. Moscow and the Gulf War. Foreign Affairs 70 (3):55-76.

Gilligan, Thomas, and Keith Krehbiel. 1989. Asymmetric Information and Legislative Rules with a Heterogeneous Committee. American Journal of Political Science 33 (2):459-90.

- 1990. Organization of Informative Committees by a Rational Legislature. American Journal of Political Science 34 (2):531-64.

Haass, Richard. 1994. Military Force: A User's Guide. Foreign Policy 96:21-37.

Hall, Peter, and Robert Franzese Jr. 1998. Mixed Signals: Central Bank Independence, Coordinated Wage Bargaining, and European Monetary Union. International Organization 52 (3):505-35.

Hawkins, Darren, David A. Lake, Daniel Nielson, and Michael Tierney, eds. 2006. Delegation and Agency in International Organizations. New York: Cambridge University Press.

Heikal, Mohamed. 1992. Illusions of Triumph: An Arab View of the Gulf War. London: HarperCollins.

Huber, John, and Charles Shipan. 2002. Deliberate Discretion? The Institutional Foundations of Bureaucratic Autonomy. Cambridge: Cambridge University Press.

Hurd, Ian. 1999. Legitimacy and Authority in International Politics. International Organization 53 (2):379-408.

- 2002. Legitimacy, Power, and the Symbolic Life of the UN Security Council. Global Governance 8 (1):35-51.

Ikenberry, G. John. 2001. After Victory: Institutions, Strategic Restraint, and the Rebuilding of Order after Major Wars. Princeton, N.J.: Princeton University Press.

Johnston, Alastair Iain. 2001. Treating International Institutions as Social Environments. International Studies Quarterly 45 (4):487-515.

Johnstone, Ian. 2003. Security Council Deliberation: The Power of the Better Argument. European Journal of International Law 14 (3):437-80.

Keefer, Philip, and David Stasavage. 2002. Checks and Balances, Private Information, and the Credibility of Monetary Commitments. International Organization 56 (4):751-74.

Khalidi, Washid. 1991. Why Some Arabs Support Saddam. In The Gulf War Reader, edited by Micah Sifry and Christopher Cerf, 161-71. New York: Random House.

Kiewiet, Roderick, and Mathew McCubbins. 1991. The Logic of Delegation. Chicago: University of Chicago Press.

Krehbiel, Keith. 1991. Information and Legislative Organization. Ann Arbor: University of Michigan Press.

Kydd, Andrew. 2000. Trust, Reassurance and Cooperation. International Organization 54 (2):325-57.

Lake, David A. 1999. Entangling Relations: American Foreign Policy in Its Century. Princeton, N.J.: Princeton University Press.

Lesch, Ann Mosely. 1991. Contrasting Reactions to the Persian Gulf Crisis: Egypt, Syria, Jordan and the Palestinians. Middle East Journal 45 (1):30-50.

Luck, Edward. 2002. The United States, International Organizations, and the Quest for Legitimacy. In Multilateralism and U.S. Foreign Policy, edited by Stewart Patrick and Shepard Forman, 47-74. Boulder, Colo.: Lynne Rienner.

Lupia, Arthur, and Mathew McCubbins. 1994. Who Controls? Information and the Structure of Legislative Decision Making. Legislative Studies Quarterly 19 (3):361-84.

Malone, David. 1998. Decision-Making in the UN Security Council: The Case for Haiti, 1990-1997. New York: Oxford University Press.

Manheim, Jarol, and Robert Albritton. 1984. Changing National Images: International Public Relations and Media Agenda Setting. American Political Science Review 78 (3):641-57.

Martin, Lisa. 1992. Coercive Cooperation: Explaining Multilateral Economic Sanctions. Princeton, N.J.: Princeton University Press.

2000. Democratic Commitments: Legislatures and International Cooperation. Princeton, N.J.: Princeton University Press.

Matthews, Ken. 1993. The Gulf Conflict and International Relations. New York: Routledge.

Maxfield, Sylvia. 1997. Gatekeepers of Growth. Princeton, N.J.: Princeton University Press. 
Milgrom, Paul, and John Roberts. 1990. Bargaining Costs, Influence Costs, and the Organization of Economic Activity. In Perspectives on Positive Political Economy, edited by James Alt and Kenneth Shepsle, 57-89. Cambridge: Cambridge University Press.

Mingst, Karen. 2003. Domestic Political Factors and Decisions to Use Military Forces. In Democratic Accountability and the Use of Military Force in International Law, edited by Charlotte Ku and Harold Jacobson, 61-80. Cambridge: Cambridge University Press.

Mueller, John. 1994. Policy and Opinion in the Gulf War. Chicago: University of Chicago Press.

News Conference of President Bush and President Mikhail Gorbachev of the Soviet Union. 1990. Weekly Compilation of Presidential Documents 26. Washington, D.C.: U.S. Government Printing Office, 1345-53.

North, Douglass, and Barry Weingast. 1989. Constitutions and Commitment: The Evolution of Institutions Governing Public Choice in Seventeenth-Century England. Journal of Economic History 49 (4):803-32.

Olson, Mancur. 1965. The Logic of Collective Action. Cambridge, Mass.: Harvard University Press.

Papayoanou, Paul. 1997. Intra-Alliance Bargaining and U.S. Bosnia Policy. Journal of Conflict Resolution 41 (1):91-116.

Pew Research Center. 2005. Trends 2005. Washington, D.C.: Pew Research Center.

Pollock, David. 1993. The "Arab Street"? Public Opinion in the Arab World. Policy Papers No. 32. Washington, D.C.: Washington Institute for Near East Policy.

Popkin, Samuel. 1991. The Reasoning Voter. Chicago: University of Chicago Press.

Powell, Colin (with Joseph Persico). 1995. My American Journey. New York: Random House.

Purrington, Courtney, and A. K. 1991. Tokyo's Policy Responses during the Gulf Crisis. Asian Survey 31 (4):307-323.

Roberts, Adam. 2004. The Use of Force. In The UN Security Council: From the Cold War to the 21st Century, edited by David Malone, 133-52. Boulder, Colo.: Lynne Rienner.

Rogoff, Kenneth. 1985. The Optimal Degree of Commitment to an Intermediate Monetary Target. Quarterly Journal of Economics 100 (4):1169-89.

Schachter, Oscar. 1989. Self-Defense and the Rule of Law. American Journal of International Law 83 (2):259-77.

Schimmelfennig, Frank. 1998/1999. NATO Enlargement: A Constructivist Explanation. Security Studies $8(2 / 3): 198-234$.

Schultz, Kenneth. 2001. Democracy and Coercive Diplomacy. Cambridge: Cambridge University Press.

_ 2003. Tying Hands and Washing Hands: The U.S. Congress and Multilateral Humanitarian Intervention. In Locating the Proper Authorities, edited by Daniel W. Drezner, 105-42. Ann Arbor: University of Michigan Press.

Shapiro, Robert, and Lawrence Jacobs. 2000. Who Leads and Who Follows? U.S. Presidents, Public Opinion, and Foreign Policy. In Decision-making in a Glass House, edited by Brigitte Nacos, Robert Shapiro, and Pierangelo Isernia, 223-45. New York: Rowman and Littlefield.

Shevardnadze, Eduard. 1991. The Future Belongs to Freedom. London: Sinclair Stevenson.

Sifry, Micah, and Christopher Cerf, eds. 1991. The Gulf War Reader. New York: Random House.

Telhami, Shibley. 1993. Arab Public Opinion and the Gulf War. In The Political Psychology of the Gulf War, edited by Stanley Renshon, 183-97. Pittsburgh: University of Pittsburgh Press.

- 2003. Aftereffects of the Iraq War in the Middle East. In the National Interest 2 (17). Available at 〈http://www.inthenationalinterest.com/Articles/Vol2Issue17/vol2issue17Telhami.html〉. Accessed 1 September 2005.

Terasawa, Katsuaki, and William Gates. 1993. Burden-Sharing in the Persian Gulf: Lessons Learned and Implications for the Future. Defense Analysis 9 (2):171-95.

Thatcher, Margaret. 1993. The Downing Street Years, 1979-1990. New York: Harper Collins.

Thomas, Ward. 2001. The Ethics of Destruction. Ithaca, N.Y.: Cornell University Press.

Thompson, Alexander. 2005. Understanding IO Legitimation. Paper presented at the 46th Annual Convention of the International Studies Association, Honolulu, Hawaii, March. 
. 2006. Screening Power: International Organizations as Informative Agents. In Delegation and Agency in International Organizations, edited by Darren Hawkins, David Lake, Daniel Nielson, and Michael Tierney. New York: Cambridge University Press.

U.S. Congress. 1991. House Committee on Foreign Affairs. Subcommittee on Arms Control, International Security and Science. The Persian Gulf Crisis: Relevant Documents, Correspondence, Reports. 102d Cong., 1st sess. June.

Voeten, Erik. 2001. Outside Options and the Logic of Security Council Action. American Political Science Review 95 (4):845-58.

- 2005. The Political Origins of the UN Security Council's Ability to Legitimize the Use of Force. International Organization 59 (3):527-57.

Volden, Craig. 2002. Delegating Power to Bureaucracies: Evidence from the States. Journal of Law, Economics, and Organization 18 (1):187-220.

Wallander, Celeste. 1999. Mortal Friends, Best Enemies: German-Russian Cooperation after the Cold War. Ithaca, N.Y.: Cornell University Press.

Weber, Steven. 1992. Shaping the Postwar Balance of Power: Multilateralism in NATO. International Organization 46 (3):633-80.

Wedgwood, Ruth. 2002. Unilateral Action in a Multilateral World. In Multilateralism and U.S. Foreign Policy, edited by Stewart Patrick and Shepard Forman, 167-89. Boulder, Colo.: Lynne Rienner.

Woodward, Bob. 1991. The Commanders. New York: Simon \& Schuster.

- 2002. Bush at War. New York: Simon \& Schuster.

Zaller, John, and Dennis Chiu. 1996. Government's Little Helper: U.S. Press Coverage of Foreign Policy Crises, 1945-1991. Political Communication 13 (4):385-405. 